\title{
Carbon Footprint Estimation of Education Building a drive towards Sustainable Development
}

\author{
J.S.Sudarsan, Jyesta W, Jaisal D
}

\begin{abstract}
Carbon footprint is the process by which the effect of carbon emission due to different activities likes using of building materials, vehicular movement, application of air conditioner etc. This kind of study plays important role in estimating the emissions happening in an institutional building. Nowadays due urbanization, Industrialization and improper development huge amount of emissions are happening in all the sector of the activity like real estate development, infrastructure development etc. This study was carried out in an educational institution to find out the amount of carbon emission happening in a particular building and due to different activities. Estimation was done using normal empirical formulas using the known constant value s and quantity of carbon emitted by different materials. It was estimated that huge amount of carbon emission is happening from the buildings, Electricity and vehicular emission in the educational institution building. The total amount of carbon emission for the entire educational campus was found to be 6772.538 tons / month. Study also carried out to access role of vegetation in absorbing the carbon emissions. Based on the study it was estimated that the vegetation plays an important role in reducing the carbon emission. Several other remedial measures like use of Rain water harvesting system, Solar panels, Vertical farming, Terrace gardening are some of the techniques can be adopted to reduce carbon emission effectively. The study helps us to know the effects of inventories that affect emission level and their action that cause changes in environment. Choice of this study is related in the present scenario of increasing $\mathrm{CO}_{2}$ levels in our very own ecological unit. By adopting several measures mentioned above, campus can be made to carbon negative. This kind of survey/estimation will help to achieve sustainable development and also it will create awareness among the public related to carbon emissions and its impact.
\end{abstract}

Keywords: Carbon footprint, Educational Institutional building, Carbon emissions, Vegetation, Carbon negative.

Revised Manuscript Received on December 5, 2019

*Corresponding Author

*Dr.J.S.Sudarsan, School of Construction management (SOCM), National Institute of Construction Management and Research (NICMAR), PUNE - 411045, India. Email: sudarsanjss@yahoo.com

Jyesta W, Advanced Construction Management, National Institute of Construction Management and Research (NICMAR), PUNE - 411045.

Email: jyestawalikar@gmail.com

Jaisal D, Advanced Construction Management, National Institute of Construction Management and Research (NICMAR), PUNE - 411045.

Email: jaisaldalal@gmail.com

\section{INTRODUCTION}

A Carbon footprint impression study can be defined as the amount of the effect of our activities on the environment, and in particular climate change [1]. It relates to the amount of greenhouse gases (GHGs) produced in our day to day lives through burning of fossil fuels for electricity, heating and transportation, etc. It is a measurement of all GHGs we individually produce and has units of tones (or kilogram) of $\mathrm{CO}_{2}$ equivalent [2].

It is also defined as a measure of carbon dioxide emissions associated with an entity's activity. It is induced by our activities and is calculated for a given time frame. A carbon footprint impression is just a number, telling you how much carbon is produced in the making, producing, transporting and using of a certain thing $[3,4]$. It offers a way to calculate the human contribution to the carbon dioxide emissions that affect the earth's atmosphere and also the climate pattern. It measures the total amount of carbon production created by our energy consumption. Knowing the carbon footprint can show areas where the carbon foot print can be decreased by several activities like energy consumption etc. and in turn, reduce the production of carbon emissions [3-6]

A Carbon footprint impression normally estimated by the sum of two parts: The Primary footprint and the Secondary footprint.

The Primary footprint is a measure of our direct emissions of $\mathrm{CO}_{2}$ from the burning of fossil fuels including domestic energy consumption and transportation. We have direct control of these emissions.

The Secondary footprint impression is the proportion of the circuitous $\mathrm{CO}_{2}$ discharges from the entire lifecycle of items we use-those related with their production and inevitable breakdown.

A Carbon footprint impression is due to the ozone depleting substances brought about by an association, occasion, item or individual through vehicle, land freedom, generation and utilization of nourishment, products, materials, wood, structures and administrations. More or less, the more we purchase, the more discharges will be caused for our benefit. The idea name of the Carbon footprint impression starts from Ecological footprint impression talk. A Carbon footprint is a subset of the Ecological footprint. The mean purpose of this research is to do

Comprehensive Life Cycle Assessment (LCA) of the institutional building. [6-10]

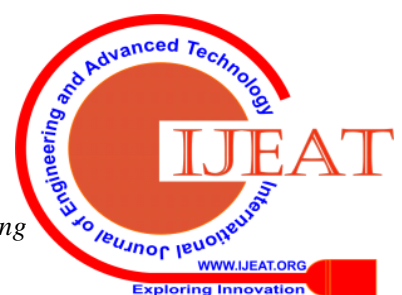


1. To calculate amount of Carbon produced by various sources.

2. To provide remedial measures to reduce the carbon produced.

3. To make the educational campus CARBON NEGATIVE.

Carbon footprint analysis has a vital role in the life cycle assessment of any infrastructure. Over the past two decades it has been observed that there is a subsequent increase in carbon content of the atmosphere. Construction technology today has reached an extreme level of advancement. These construction activities have an adverse effect on the environment.

Thus, it is crucial to study these effects and develop methods to neutralize this effect of carbon. Rapid urbanization has also contributed to the Carbon content. Carbon in the atmosphere has the ability to capture and retain heat. This in turn leads to global warming..

\section{MATERIALS AND METHODOLOGY}

The method adopted for estimating carbon footprint impression was expressed in the following steps.

Step I: Describing the carbon footprint impression.

Step II: Measuring the carbon footprint and Emission inventory survey.

Step III: Identifying maximum carbon emission source.

Step IV: Estimating carbon reducing/absorbing source.

Step V: Mitigation measures.

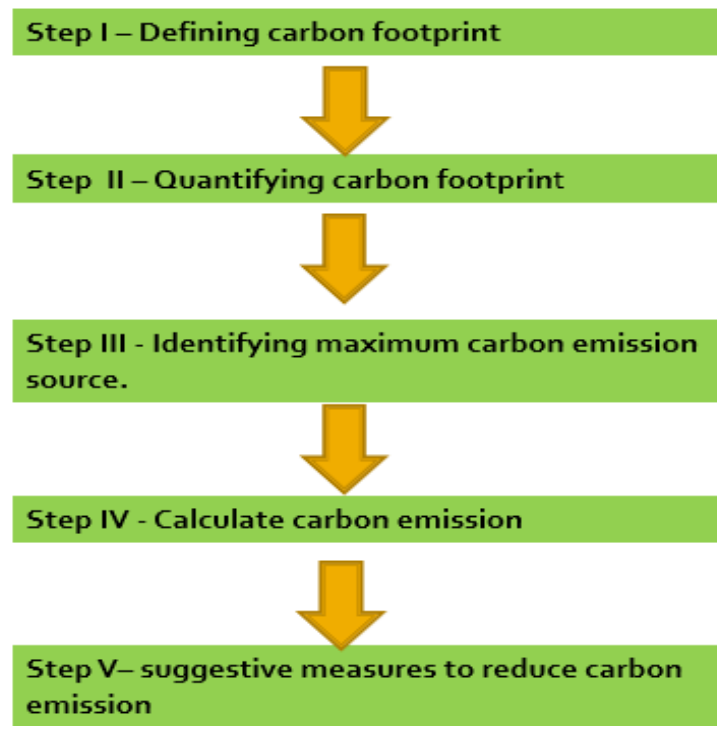

Fig. 1.Methodology Flow Chart

The above five steps were followed in executing the research study.

\section{A. Study area}

Site located in Belagavi Karnataka state. Belagavi district also called as Belgaum and it is located in the north western corner of Karnataka state. This district shares the border with Goa in one side and Maharashtra in other side. This district is located at a Mean Sea Level of 450 to $900 \mathrm{~m}$. The climatic condition in this district is pleasant and even in the month of May the night hours are cool and moist climate will prevail during the month of June to September. The maximum rainfall in the study area found to be 60 to $79 \mathrm{~mm}$ average during the study period and temperature found to 23 to 29 degree Celsius during the study period. As the temperature in the study area not going beyond $31^{\circ} \mathrm{C}$ and situation is quite suitable for developing greenery and green cover it plays an effective role in reducing the carbon emission and to convert the particular structure in to carbon negative [10-12].

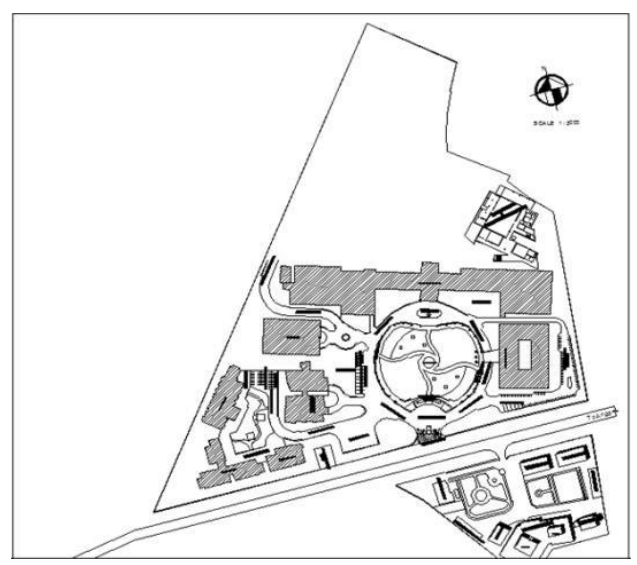

Fig. 2.Study area Map

The total buildup area of the institute also found to be around $39655.44 \mathrm{~m}^{2}$ and the total build up area of the plinth was around $11978.87 \mathrm{~m}^{2}$. Total population of the institution was found to be around 3000 which include hostellers, day's scholars and other staff members. Sampling Frame Work: It was done through Principal data collection and ancillary data collection for a period of eight months in two phases starting from June to March 2017- 2018. First phase consisting of collecting the data related to carbon emitting sources and categorizing the same and second phase consists of carbon reduction estimation through different sustainable measures. The data collected was analyzed and the same was compared with the guidelines specified by different agencies like green building council of India and Con-federation of Indian Industry (CII) [11-13].

\section{ANALYSES}

The main purpose of this study is to analyze the carbon footprint that contributes to global warming and to make the educational campus carbon negative. Carbon footprint is formed due to various carbon emitting inventories that have been analyzed as follows.

The selected inventory details are to be collected and should be analyzed for carbon footprint of the campus.

\section{EMISSION INVENTORY SURVEY}

Feasible emission inventories are to be selected to analyze the Carbon footprint of the campus. The inventory survey was done for one academic year in two phases and different inventories are selected for carbon foot print estimation [14- 21].

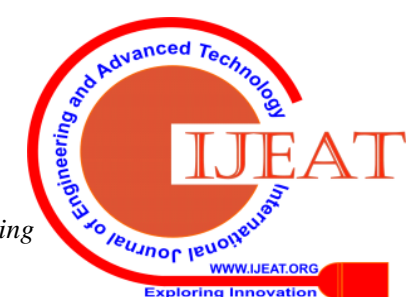




\section{RESULTS AND DISCUSSION}

The inventories chosen are Human Factor, Transportation, Electricity, Solid Waste, Production and Consumption of Food, LPG, Natural Gas, Buildings. Information managers are distinguished and the essential subtleties are gathered. Parameter wise and zone wise details are collected. The received data are assembled and the Missing gaps are recognized and the through reference data the emission inventory was calculated and the amount carbon emission through the different inventory was estimated and the same tabulated in table 1 .

Table- I: Carbon Emission through various factors on campus

\begin{tabular}{|c|c|c|c|}
\hline $\begin{array}{r}\text { EMISSION } \\
\text { INVENTORY }\end{array}$ & $\begin{array}{l}\text { EMISSION } \\
\text { FACTORS }\end{array}$ & QUANTITY & $\begin{array}{l}\text { CARBON } \\
\text { EMITTED( } \\
\text { KG/MONTH) } \\
\end{array}$ \\
\hline $\begin{array}{l}\text { 1. Human } \\
\text { factor }\end{array}$ & $\begin{array}{c}1.14 \\
\text { Kg/person/day }\end{array}$ & 2800 & 37620 \\
\hline \multirow{2}{*}{$\begin{array}{c}2 . \\
\text { Transportation }\end{array}$} & $\begin{array}{l}\text { Petrol -2.3 } \\
\text { Kg/lit }\end{array}$ & 704 & \multirow[b]{2}{*}{5272.8} \\
\hline & $\begin{array}{l}\text { Diesel-2.7 } \\
\text { Kg/lit }\end{array}$ & 8 & \\
\hline 3. Electricity & $0.689 \mathrm{Kg} / \mathrm{kwh}$ & $\begin{array}{l}67758 \\
\text { kwh }\end{array}$ & 46723.2 \\
\hline 4.Solid waste & $\begin{array}{c}0.125 \mathrm{~kg} / \\
\text { person / day }\end{array}$ & 2800 & 7185 \\
\hline $\begin{array}{c}\text { 5.Food } \\
\text { production and } \\
\text { consumption }\end{array}$ & $\begin{array}{r}17 \% \text { of total } \\
\text { food production }\end{array}$ & $177 \mathrm{kgs}$ & 902.7 \\
\hline $\begin{array}{c}\text { 6.LPG and } \\
\text { Natural gas }\end{array}$ & $\begin{array}{l}1.5 \mathrm{~kg} / \mathrm{kg} \text { of } \\
\mathrm{LPG}\end{array}$ & $1780 \mathrm{kgs}$ & 2670 \\
\hline 7.Building & $\begin{array}{c}28 \mathrm{~kg} \text { per } \\
\text { square meter of } \\
\text { brick work }\end{array}$ & $39655.44 \mathrm{~m}^{2}$ & 1110352.32 \\
\hline \multirow{3}{*}{$\begin{array}{l}\text { 8. Electrical } \\
\text { equipments }\end{array}$} & $\begin{array}{l}\mathrm{A} / \mathrm{C}-0.018 \\
\mathrm{~kg} / \text { hour }\end{array}$ & 21 & \multirow{3}{*}{1049812} \\
\hline & $\begin{array}{l}\text { Refrigerator- } 0 \\
.05 \mathrm{~kg} / \text { hour }\end{array}$ & 9 & \\
\hline & $\begin{array}{c}\text { Laptops } \\
-14.38 \mathrm{~kg} \text { per } \\
\text { month }\end{array}$ & 4100 & \\
\hline $\begin{array}{c}\text { 9. Water } \\
\text { consumption }\end{array}$ & $0.376 \mathrm{~kg} /$ litre & $\begin{array}{l}12000000 \\
\text { litres }\end{array}$ & 4512000 \\
\hline $\begin{array}{r}\text { TOTAL } \\
\text { CARBON } \\
\text { EMITTED }\end{array}$ & & & 6772538.02 \\
\hline
\end{tabular}

The factor at study conducted on campus to check the amount of carbon absorbed through various factors are discussed and the difference between the carbon emitted and carbon absorbed is also considered for which different remedial measures are suggested [22-23]. The main components absorbing carbon within the campus are the present green cover that is trees and area of grass grown. The amount of carbon absorbed by the trees and grass was estimated using secondary data related to the amount of carbon absorbed by matured tree (Trunk dia $>$ or $=12$ inches) multiplied with the number of matured trees.

Amount of carbon absorbed within campus

Number of matured trees $=224$

Average amount of carbon absorbed by a mature tree $=20000 \mathrm{~kg} / \mathrm{month}$ [24]

Amount of carbon absorbed by campus greenery $=224 \times 20000=4480000 \mathrm{~kg}$.
In the same way other sustainable concepts like solar, rain water harvesting and terrace gardening also calculated using the secondary data as a reference and same was represented in the fig 2 .

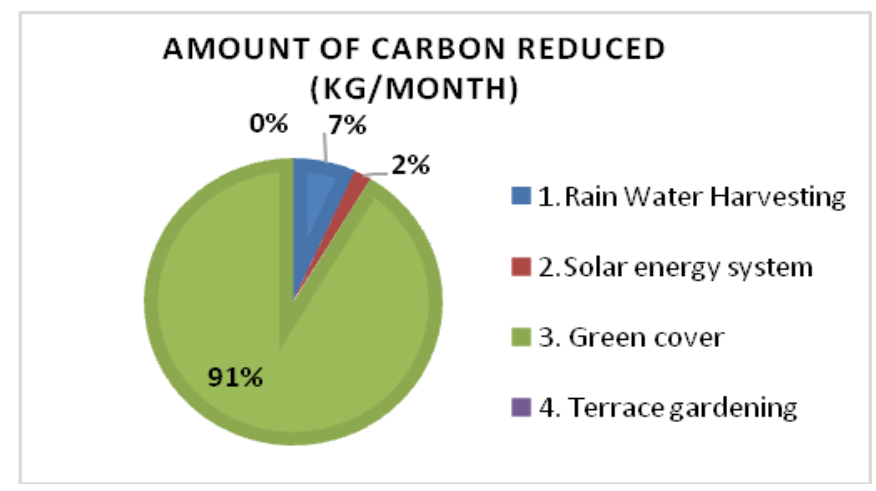

Fig. 3.Carbon Reduction

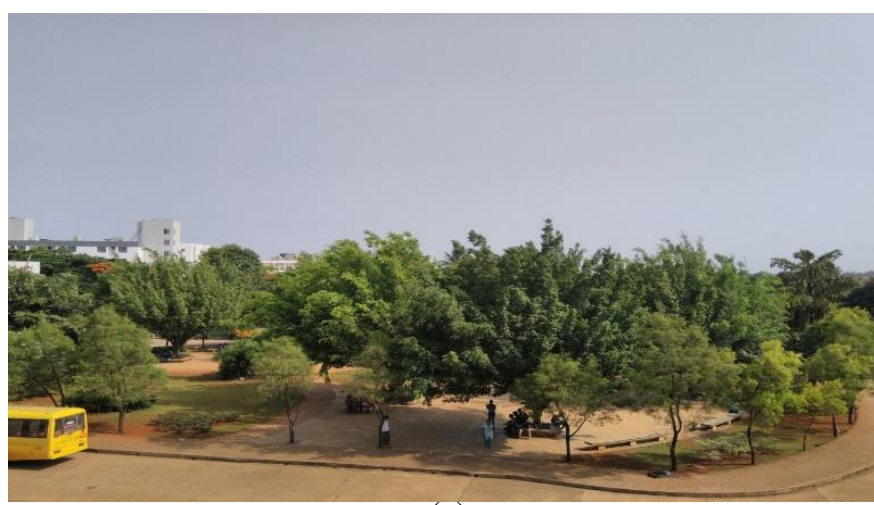

(a)

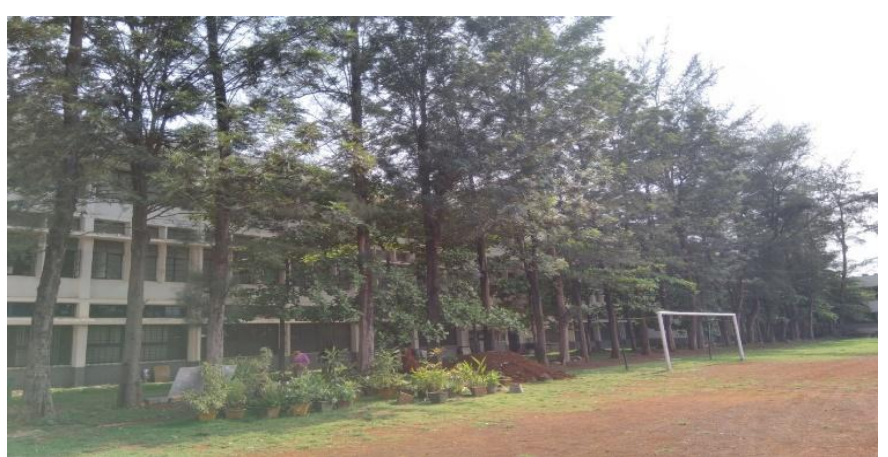

(b)

Fig. 4.Green cover

The carbon positive campus is now converted into carbon negative by adopting different methods like use of Rain water harvesting system, Solar panels, vertical farming, terrace gardening are adopted to reduce carbon effectively. The study helps us to know the effects of inventories that affect emission level and their action that cause changes in environment. A pit has to be constructed for storage of rain water behind civil maintenances room. Solar panels are proposed to be installed over MBA block, E\&C block and CIVIL block. Terrace gardening is proposed over Main building, Boys Hostels, Canteen and Workshop. Vertical farming can also be adopted to reduce the carbon content. It can be done on peripheral walls up to sill level, also on continuous chejjas.

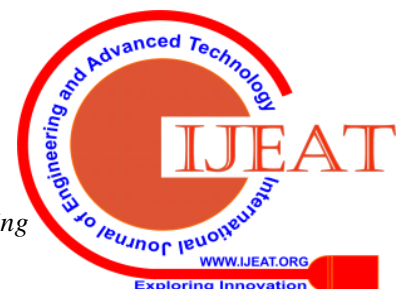


These kind of study is highly important and very much relevant in the current scenario of rising $\mathrm{CO}_{2}$ levels in our very own ecosystem. By adopting the various measures mentioned above, campus can be made carbon negative. Hence campus is made CARBON NEGATIVE based on the adaptation of the following abovementioned sustainable techniques.

\section{CONCLUSION}

As Infrastructure industry and real estate sector is consuming major part of renewable and nonrenewable energy they are major contributor for the carbon and greenhouse gas. Based on the study it was estimated that in the institution building major contributor for greenhouse gas and carbon was found to be Building > water consumption > electrical equipment $>$ Electricity $>$ Human factor $>$ Solid waste $>$ Fuel consumption $>$ food production. To be with nature and convert the carbon positive to carbon negative several initiatives were proposed and implemented making the entire institution building carbon negative, thus supporting sustainable growth.

It was found that the building was the highest source for carbon emission whereas food production was the least. Increasing in the green cover proved to be the most economic and effective measure for reducing the emission level.

This has to be looked into and tested for anticipated outcomes, for which all partners' commitment required.

\section{Conflict of Interest}

The authors declare no conflict of interest.

\section{ACKNOWLEDGMENT}

The authors are very much grateful to the educational institutional authorities of Belagavi, Karnataka for providing data to execute this research study and also authors are very much thankful to director general of National Institute of Construction Management and Research (NICMAR), Pune and the Dean School of Construction management for their continuous support and encouragement.

\section{REFERENCES}

[1] Asif, M.; Muneer, T.; Kelley, R. Life cycle assessment: A case study of a dwelling home in Scotland Build. Environ. 2007, 42, p.1391-1394.

[2] Allen et.al., Warming caused by cumulative carbon emission: the trillionth tone, Nature, 2009, 458 (7242), p.1163-1166.

[3] Buyle, M.; Braet, J.; Audenaert, A. Life cycle assessment in the construction sector: A review. Renew. Sustain Energy Rev. 2013, 26, p.379-388.

[4] Zhang, J., Xu, L., 2015. Embodied carbon budget accounting system for calculating carbon footprint of large hydropower project. J. Clean. Prod. 96, p. $444-451$

[5] Chau, C.K.; Leung, T.M.; Ng,W.Y. A review on life cycle assessment, life cycle energy assessment and life cycle carbon emissions assessment on buildings. Appl. Energy 2015, 143, p.395-413.

[6] Dossche, C.; Boel, V.; De Corte, W. Use of Life Cycle Assessments in the Construction Sector: Critical Review Proc. Eng. 2017, 171, p.302-311.

[7] Ernest. Worrell et al, 2001. Carbon dioxide emissions from the global cement industry, Annual review of energy and the environment, 26: p.303- 329. [8] Giesekam, J.; Barrett, J.R.; Taylor, P. Construction sector views on low carbon building materials. Build. Res. Inf 2016, 44, p.423-444.
[9] Junnila, S., Horvath, A., 2003. Life-cycle environmental effects of an office building. J. Infrastruct. Syst. 9 (4), p.157- 166.

[10] Krister Anderson et.al, 2009. National forest carbon inventories: policy needs and assessment capacity, Climate change, 93: p.69-101.

[11] Lenzen and Shauna A. Murray, The ecological footprint - Issues and trends, ISA Research Paper, The University of Sydney, 2003,p. 01-03.

[12] Matthias Finkbeiner, 2010. Carbon foot printing- opportunities and threats, The international journal of life cycle assessment, 14: p.91-94.

[13] Michael Knaus, Dirk Löhr and Bernadette O'Regan, Valuation of ecological impacts - a regional approach using the ecological footprint concept, Environmental Impact Assessment Review, 2006,26, p.156.

[14] Matthias Finkbeiner, 2010. Carbon footprinting- opportunities and threats, The international journal of life cycle assessment, 14: p.91-94.

[15] Meinshausen et al., 2009. Greenhouse-gas emission targets for limiting global warming to $2^{\circ} \mathrm{C}$, Nature; 458 (7242): p.1158-1162.

[16] Nie Zuoren: 'The carbon footprint and energy saving and emissionreduction',Mater. China, 2010,2, 60-63. [17] Per-Anders Hansson et.al, 2010. Uncertainties in carbon footprint of food products: a case study on table potatoes, The international journal of life cycle assessment, 15:p. 478-488.

[18] Radhi, H.; Sharples, S. Global warming implications of facade parameters: A life cycle assessment of residential buildings in Bahrain. Environ. Impact Assess. Rev. 2013, 38, p.99-108.

[19] Ramesh, T.; Prakash, R.; Shukla, K.K. Life cycle energy analysis of buildings: An overview. Energy Build 2010, 42, p.1592-1600.

[20] Schwartz, Y.; Raslan, R.; Mumovic, D. The life cycle carbon footprint of refurbished and new buildings A systematic review of case studies. Renew. Sustain. Energy Rev. 2018, 81, p.231-241.

[21] Wright.L et.al, 2011. 'Carbon footprinting': towards a universally accepted definition, Carbon management, 2(1): p.61-72.

[22] Weidema, B.P.; Thrane, M.; Christensen, P.; Schmidt, J.; Lokke, S Carbon footprint: A catalyst for life cycle assessment J. Ind. Ecol. 2008, 12,p.3-6.

[23] Wu Yuping and Ge Wei: 'Improve construction energy reductionpolicy, promote the energy-efficient development of construction inChina',China Construct. Heating Refrig., 2007,4, p.16-20.

[24] You, F.; Hu, D.; Zhang, H.; Guo, Z.; Zhao, Y.; Wang, B.; Yuan, Y. Carbon emissions in the life cycle of urban building system in China-A case study of residential buildings. Ecol. Complex. 2011, 8,p. 201-212.

\section{AUTHORS PROFILE}

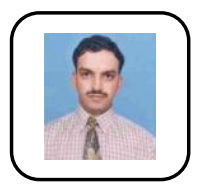

J.S.Sudarsan, Assistant Professor having more than 2 decade of teaching and 12 years of researchexperience. He published more than 35 articlesin reputed journal and published 2 text books

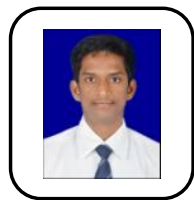

Jyesta W, Post Graduate student in construction management at NICMAR Pune, certified IGBC Accredited Professional.

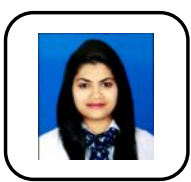

Jaisal D, Post Graduate student in construction management at NICMAR Pune, certified IGBC Accredited Professional. 